\title{
Access and Social Capital: A Profile of Community College and Global Counterparts
}

\author{
Rosalind Latiner Raby ${ }^{\mathrm{a},{ }^{*}}$ and Edward J. Valeau ${ }^{\mathrm{b}}$ \\ ${ }^{a}$ California State University, Northridge, USA \\ ${ }^{b}$ Hartnell Community College, USA
}

\begin{abstract}
Alternatives to the traditional four-year public and private university include a sector of higher education that offers a more advanced curriculum than secondary school and serves as a local and often lower-cost pathway that gives options for university overflow for adult learners, displaced workers, lifelong learners, workforce learners, developmental learners, and non-traditional learners (Raby and Valeau 2009). These institutional types are known by several names including College of Further Education, Community College, Polytechnic, Technical College, and Technical and Further Education (TAFE) and are found on all continents. Based on a literature review of 1,083 academic publications these institutions share a mission that views educational access as necessary for growing the economic and social capital that is needed to help students improve lives. Central to this mission is the belief that any amount of post-secondary education is life-enhancing, regardless of length of study or level of completion. This article examines application of this mission at community colleges and global counterparts throughout the world.
\end{abstract}

\begin{abstract}
Abstrak
Alternatif dari kuliah empat tahun di universitas negeri atau swasta adalah unit perguruan tinggi dengan kurikulum lanjutan dari sekolah menengah, berfungsi sebagai jalur lokal dengan biaya terjangkau, dan menyediakan opsi pendidikan setara universitas bagi mahasiswa usia dewasa, karyawan yang direlokasi, mahasiswa segala usia (lifelong learners), mahasiswa pekerja, mahasiswa tingkat lanjut, dan mahasiswa non-tradisional (Raby and Valeau 2009). Beberapa institutisi sejenis ini meliputi College of Further Education, Community College, Polytechnic, Technical College, dan Technical and Further Education (TAFE) dan berada di seluruh benua. Berdasarkan kajian literature dari 1.083 publikasi akademik, institusi-institusi tersebut mempunyai misi sama yang memandang pentingnya akses pendidikan bagi pertumbuhan ekonomi dan kapital sosial untuk peningkatan taraf hidup. Prinsip utama dari misi mereka adalah bahwa pendidikan tinggi merupakan upaya peningkatan hidup, apapun jenjangnya dan berapapun lamanya. Artikel ini menganalisa implementasi misi sejumlah perguruan tinggi lokal dan internasional di seluruh dunia.
\end{abstract}

Key Words: Community College, College of Further Education, Polytechnic, TAFE, Access, Social Capital, Economic Capital, Non-traditional Students

\section{Introduction}

Higher education includes a diverse and increasingly varied selection of post-secondary institutions. Alternatives to public and private four-year universities include a sector that offers a more advanced curriculum than secondary school and serves as a local and often lower-cost pathway that gives options for university overflow for adult learners, displaced workers, life-long learners, workforce learners, remedial or developmental learners, and nontraditional learners (Raby and Valeau 2009, p. 10). The institutions

* Corresponding author. Address: California State University, Northridge, 20630 Romar St. Chatsworth, CA 91311. Email: rabyrl@aol.com. found in this sector exist worldwide and are known by several names including College of Further Education, Community College, Polytechnic, Technical College, and Technical and Further Education (TAFE).

There is a noted absence of a universally acknowledged term for these institutions because they maintain such different organizational structures, curricula focus and geographic locations. In fact, over 50 names exist by which academics and policy makers refer to these institutions (e.g., higher colleges of technology; Jr. college; university colleges), academic levels (upper-secondary, post-secondary; pre-baccalaureate); length of study (short cycle; short-term; two-year); type of study (post-compulsory; tertiary, non-university); and context of curriculum (lifelong education, transfer education, vocational education). Despite sharing noted 
similarities, the lack of a universally accepted term makes crossnational comparisons difficult.

We recognize that the term community college is vague, even in those countries where these institutions exist. Complicating this discussion is a stereotyping of the community college as a United States phenomena, which leads to a misinterpretation of form and a lack of acknowledgement that these institutions exist in many countries (Raby and Valeau 2013). In fact, in our review of 1,083 publications, we found that no other institutional type within this sector is found in as many countries as the community college. Moreover, as a result of the politics of borrowing, where multiple countries affect the discourse of other countries, non-United States authors are increasingly using the term community college to refer to this sector within their own countries. Thus, we use the term community colleges and global counterparts to define a cohort of institutions to facilitate comparison and understanding.

Four characteristics define the institutional type we are calling community colleges and global counterparts. While a variety of institutions around the world may share one or a few of these four characteristics, only those in this cohort share all four characteristics. These institutions (a) have unique missions in which professional and academic programs are linked to serve local communities (Raby and Valeau 2009; Wiseman, Chase-Mayoral, Janis, and Sachdev 2012); (b) offer options for university overflow and a "second chance" for non-traditional students who have long been excluded from higher education (Kintzer 1994; Elsner, Boggs and Irwin 2008); (c) offer curricula to meet regional medium term labor requirements in high demand occupations in changing economies (Levin 2001); and (d) support a mission that views educational access as necessary for providing economic and social capital that is needed to ensure social prosperity (de Moura and Garcia 2003; Treat and Haggadorn 2013). Based on a literature review from 1971-2014, this article focuses on the characteristic which identifies the use of educational access to support growth in social capital.

\section{Methodology}

In 2012, we conducted a literature review of print and on-line peer review journal articles, chapters in books, dissertations, and ERIC documents written in English from 1971-2010 (Raby and Valeau 2013). For this article, we added publications from 20112014 as well as new publications found from earlier years. To date, we reviewed 1,083 publications of which 659 were peerreview journal articles and 424 were book chapters, dissertations and ERIC documents. We continue to use 1971 as a start date because that is the date of the earliest publication that highlights community colleges and global counterparts in a comparative mode. We acknowledge that a focus on only English language sources ignores a wealth of publications (Raby 2010). However, in that over half of the authors in our search were from countries other than the United States and Canada who wrote about institutions in their home countries, we submit that the process of selecting publications published in English maintains validity and credibility of cross-cultural and comparative analysis.

We used three search designs to locate and then analyze sources using the same set of key-terms: (1) peer-review articles listed in the Comparative Education Review Annual Bibliographies from 1971-2014; (2) peer-review articles and ERIC documents in ERIC, EBSCOhost Research Databases, PROQUEST academic databases, IDP Database of Research on International Education, and Australian Council for Educational Research databases from 1971-2014; (3) Google search for published books, chapters in books, dissertations, and institutional reports. Once sources were identified, a multi-part data analysis included a quantitative charting of the type of publication and geographical focus followed by a qualitative content analysis of related themes and common characteristics. Data was divided into segments, labeled and examined for overlap and redundancy and then collapsed into layers of themes as prescribed by Spindler and Spindler (1992).

Publications were identified based on the process defined by the Comparative Education Review Bibliography (Raby 2010) in which all publications for the review had to have a title that reference (a) a country and/or region outside of the United States and (b) a socio-cultural, economic, environmental or political characteristic that in some way impacts education. For this review, we added an additional criterion: all titles must contain one of our identified keywords. Publications that did not include these criteria were excluded from the search. Additional keywords were accumulated as the publications were diversified. All identified publications underwent a final keyword search to assure proper identification. Finally, the qualitative content analysis then revealed those publications that matched the community college and global counterpart four-part definition found in the introduction of this article. This was a necessary step because sometimes the same key-term denoted institutions that could be included in the analysis (i.e., included all four defined characteristics), while other times, it could not. This was especially true when examining publications connected to Technical Education (TE), Technical Education Training (TET), Technical Vocational Education (TVE), Technical and Vocational Education and Training (TVET), Vocational Education (VE), Vocational Education and Technology (VET) Vocational-Technical Education (VTE); and Vocational Training (VT).

Our review clearly shows that institutions that match our fourpart definition do circumvent the world. Of these publications, 353 
publications focused on community colleges and global counterparts in Europe, of which most of the articles focused on the United Kingdom, followed by Germany, Netherlands, and Russia; 291 publications that focused on Australia and New Zealand; 167 publications described Asian institutions with most of the studies highlighting China, Hong Kong, India, Japan, Thailand, and Viet Nam; 87 publications described institutions in African and mostly focused on South Africa, Uganda, and Northern Africa and 49 publications focused on Latin America with the majority showcasing countries in the Caribbean. The remainder of the publications were from a Canadian or United States comparative base or focused on multi-country comparisons.

\section{Access}

A Substantial literature exists on the importance of access and resulting massification for higher education (Trow 1973; Scott 2010). While massification is commonly connected to universities, it also refers to the expansion of "non-university institutions" (Teichler 2004; Scott 2009). A demonstration of massification is the largely non-restrictive admission process of community college and global counterparts that has lead to extremely large student enrollments (Raby and Valeau 2009; Wiseman et. al. 2012; Organisation for Economic Co-operation and Development [OECD] 2014). Over the past decade, these institutions continue to experience both an "absolute growth in student enrollments as well as a more egalitarian distribution of students in higher education" (Jansen 2003, p. 292).

The discussion of open access is not one that directly advocates for equity. It simply provides a context for non-competitive admission. In the sector under study, students frequently enroll because the opportunity exists based on open access policies. For some students, there is even a preferred choice to attend a community college or global counterpart because of lower-cost tuition and fees, local geographic locations, and specific opportunities for non-traditional student admission.

Lower-Cost. Flexible fee structures are commonly found in community colleges and global counterparts throughout the world. Even in countries where private tuition and costly entrance exams do pre-select, these institutions still are a lower-cost alternative and thus attract a largely different population than the ones courted by four-year public and private universities. Lower cost is a noted reason for attendance in community colleges in Viet Nam (Epperson 2012) and India (Alphonse and Valeau 2009).

Local Geographic Locations. Many community colleges and global counterparts are purposefully located in remote rural or urban areas to serve neglected populations. The physical placement facilitates enrollment as the geographical proximity to home al- lows students to think about their options to attend higher education. It is geographical closeness to home that is most noted as a key element for choosing to attend Canadian CÉGEPS (BèginCaouette 2013), Japanese Jr. Colleges (Anzai and Paik 2012), and Jordan community colleges (Allaf 2012-2013).

Admission for Non-Traditional Students. Open access impacts non-traditional students who have been excluded from higher education due to social status, poverty, race, ethnicity, gender or age. Student demographics include women, working and lower class adults, and seniors. Students often balance study, work and family/personal lives, which add to their non-traditional student status. Mission statements explicitly mention a goal to increase access for non-traditional students as is seen in Scottish Further Education Colleges (Lowe and Gayle 2007) and Turkish Vocational and Schools of Higher Educational [VSHE] (Aypay 2008).

\section{Educational Links to Grow Social and Human Capital}

All of the publications in our search maintain a philosophical belief that education is key for societal change and that these opportunities, especially for the disenfranchised, change lives. Rooted in human capital theory (Schultz 1961; Psacharopoulous and Woodhall 1985) and social-cultural capital theory (Bourdieu and Passeron 1977), literature shows that the access provided by community colleges and global counterparts have positive consequences for social mobility as the more educated gain better employment opportunities that provide an opportunity to gain higher standards of living. It is proposed that this connection is so strong that the mere absence of a community college or global counterpart is linked to under-preparation which translates into high levels of un- and under-employment, poverty and inequity (Kintzer 1979; Strydom and Lategan 1998; de Moura and Garcia 2003; Lewin 2007; Wisemen et al. 2012; Panwar 2013).

The literature provides examples in which community colleges and global counterparts have instituted policies and specific programs to become change agents and directly influence student choices, engagement, and learning. Examples include entrepreneurial education programs in Canada (Nixon 2011) and Ireland (DoBell and Ingle 2009) that link education to employment opportunities and institutional quality assurance programs in Qatar (Spangler and Tyler 2011) that are designed to ensure programmatic sustainability. Student focused reforms seek to improve learning and success are seen in Mali (Glander-Dolo 2011), Senegal (Gueye and Sene 2009), Australia (Riordan 2008), England (Hall and David 2008), and New Zealand (Scott 2009). In all these programs, positive changes result from simply attending these specific programs offered by a community college or global counterpart. 
The extent to which education enhances social and human capital and improves lives does depend on a variety of factors. Similar to discussions of massification, the consequences of attendance "is successful in delivering fairer access but less dynamic in terms of promoting social mobility" (Scott 2009, p. 21). For community colleges and global counterparts, actual success depends upon the type of education offered (technical/vocational, personal development, professional, or academic) and if this education has a relevancy of the curriculum to the economic needs of the society (Raby and Valeau 2009). Success is also contingent on the type of student targeted in terms of the level of college readiness, the relationship of the type of education to the college's mission, and what students actually do with this education.

\section{Examples Where Educational Access Enhances Social Capital}

Challenging societal inequalities via access to education is a goal of community colleges and global counterparts. Of the publications reviewed, more than half gave specific examples that show how their open access policies provide avenues for social capital attainment by non-traditional students, regardless of completion. The premise found in these publications suggests that there are benefits that result simply by attending a community college and global counterpart. In the United States, some of these benefits result from gaining skills that result in wage increases, improvement of job prospects, and gains in their own physical and mental health (Mullin 2011). Emphasis on opening access to nontraditional populations is part of documented successful outreach campaigns that have resulted in increased participation of underprivileged youth in Venezuela (de Moura and Garcia 2003), of immigrant communities and women in the United Kingdom (Scofield and Dismore 2010), of academically unprepared students in the United States (Roska and Calcagno 2010), and of nontraditional students in New Zealand (Scott 2009).

Unique to community colleges and global counterparts is that by design so many educational programs are terminal and result in certificates that are designed to enhance work-place entry and that target job advancement (World Bank 2008; Chen 2009). The common theme in the reviewed literature is that access to workforce specific educational programs at community colleges and global counterparts does result in employment opportunities as shown in Poland and Canada (Butler, Smith, and Davidson 2008), in Barbados and Jamaica (Morris 2012), and for women in Japan (Anzai and Paik 2012). One example is that as of 2012, 82 percent of Tunisia Higher Institutes of Technology Studies graduates found a job within six months of graduation (Shumaker 2012). Literature is also beginning to confirm that students do not need to complete a degree program to enhance social capital needed for employment gains. Herault, Zakirova, and Buddelmeyer (2012) show that participation in even some tertiary education in Australia brings higher wage earning. Similarly, in the United States, even those with only a certificate (as opposed to a degree) can gain the type of employment that results in a significant economic gain (Carnevale, Rose, and Hanson 2012).

It is interesting to also note that authors writing from and about countries other than the United States and Canada acknowledge stratification as an inherent component which is being specifically addressed by the existence of educational reforms that promote access. Even authors who are critical of these institutions in terms of reaching full societal change do not question the merits that even limited education can provide. In this context any job is better than unemployment and any education is important, no matter how small the impact (de Moura and Garcia 2003; Chen and Wang 2009; Wiseman et al. 2012; Panwar 2013).

\section{Examples Where Access Does Not Enhance Social Capital}

Entry alone is not a guarantee of completion or success. Open access results in students who have a range of abilities and who experience differential progression. Some students do not have the academic preparation to succeed in college level courses, others do not have the social capital to know how to achieve their goals, and still others are tracked into low level programs which have limited levels of progression (Jephcote and Raby 2012; Longden 2013). As a result, open access has positive outcomes for some students while simultaneously being less successful for others.

For those students who do achieve completion, the education received at the community college and global counterpart is not always perceived as advantageous and often these institutions are seen by government, employers, academics, and the public as "lesser-than" institutions. Low status is compounded by institutions being located in rural or low-income areas (Wiseman et al. 2012) and by having a largely non-traditional student population (de Moura and Garcia 2003). Resulting stereotypes of graduates as being less trained and less competitive than those who attend fouryear universities impact job attainment as seen in Latin America (Marmolej 2010), in Japan (Anazi and Paik 2012), and in Canada (Levin 2001). The lower status, in turn, results in a smaller budget for operations. Consequences of a low budget are higher studentfaculty ratio, lower faculty salary, less student support services, and less funds allocated to building upkeep, all of which negatively affect student achievement (Jephcote 2011). Low prestige and limited budget reinforce a context in which elite students are now choosing to attend four-year universities instead of using the community college and global counterpart as a pipeline, such as in Israel (Davidovich and Iram 2009). In turn, larger numbers of 
lower-ability and lower-economic students attend community colleges or global counterparts, which further reinforces a stratified educational system, such as in Mexico (Gregorutti 2012).

The combination of low status and low perception further discriminates against graduates as education may not be a guarantee for future employment. In Zimbabwe, low status forced graduates to find employment abroad (Mpondi 2009). In Lebanon, 27 percent of the officially unemployed held Intermediate Diplomas from community colleges (Meehan 2012). While many of the reviewed publications celebrate the link between education and postgraduation employment, there is no guarantee that such employment is commensurate with a level of study achieved. In this context, the potential for social mobility even for those who complete their community college or global counterpart education may not be enough to counter societal inequalities.

Levin (2001, pp. 4-5) claims that "as long as community colleges are seen as a pipeline to the university, instead of a separate field, the lowered status will continue." Indeed, for over a decade, several community college and global counterparts have been changing their missions (called mission creep) and even their names to gain prestige. This happened in Israel (Davidovitch and Iram 2009), in Chile (Li 2010), and most recently in Canada with the re-branding of the Association of Canadian Community Colleges as Colleges and Institutes Canada (Colleges and Institutes Canada 2014).

\section{Conclusions}

Based on a literature review of 1,083 English language academic publications from 1971-2014, this article illustrates how community colleges and global counterparts are making an impact throughout the world by supporting open access policies. These institutions are redefining who can get a higher education and in so doing are diversifying higher educational student populations. Since these institutions offer participation to the widest margins of society, they tend to serve as a symbol of equity. While not consistent in all countries, institutions with low tuition, geographic accessibility, and open access tend to provide opportunities as is illustrated by the percentage and diversity of students that attend these institutions. Impact is being made in that large numbers of students do enter these institutions and there are noted increases in completion as well. The expansion of community colleges and global counterparts underscore the degree by which they have made their mark in higher education.

One such mark is the use of education to create a foundation upon which economic and social capital can be accumulated. For some students, a non-traditional profile may limit options to attend only a community college or global counterpart. For other stu- dents, they choose the community college or global counterpart because of unique curricular offerings, lower-cost, and local geographic placement of these institutions. Benefits gained by community colleges and global counterparts include skills to increase job attainment or advancement, skills to enhance intellectual capital and critical thinking, and skills to inform community building. Research shows that when individuals gain such skills they have easier entry to jobs that in turn provide options for social mobility (Chen 2009; Herault, Zakirova, and Buddelmeyer 2012; Carnevale, Rose, and Hanson 2012; Panwar 2013). Much of the literature confirms that alternative pathways given by community colleges and global counterparts do provide educational opportunities to students that are life-enhancing.

Despite the noted benefits of attending a community college and global counterpart, there are deep-rooted societal and institutional inequalities that are difficult to counter. Increased access for those whose individual academic skills, level of college preparation, and lack of social capital may not result in significant success. Socio-economic barriers and prejudices continue to reinforce that not all students will succeed in a community college or global counterpart as so many are tracked into lower-status studies which labels graduates as not having the same competitiveness as their university counterparts. Finally, the limited prestige of these institutions support patterns in which the more elite students in a society choose to not attend a community college and global counterpart which further marginalizes those who remain.

Although patterns that enhance socioeconomic stratification exist, the intent to use access as a societal equalizer remains a dominant discourse. It is maintained that even with limited options that result from a community college and global counterpart education, the resulting employment is still superior to what students would achieve without this education. As such, regardless of length of study, be it short term, certificate or degree based, or even if a program is not completed, the educational experience in itself is life-transforming and as such enhances social capital, especially for the less educated.

In conclusion, the attempt to sustain affordability and yet maintain educational quality and relevance is a constant battle across all community college and global counterparts (Commons 2003; Harbour and Ozan 2007; Katsinas and Tollefson 2009; Hagedorn and Mezghani 2012; Wiseman et al. 2012). This dynamic is problematic since the image of affordable education is central to the application of open access and the widespread growth of community college and global counterparts. Future empirical and comparative research, which will include publications written in languages other than in English, will continue to explore the patterns presented in this article. 


\section{References}

Allaf, Carine. 2013. "Women's Perspectives on Retention in Higher Education in Jordan: Commute and Choice Detail Only Available." Journal of College Student Retention: Research, Theory \& Practice 14 (1): 67-89.

Alphonse, Xavier S. J., and Edward J. Valeau. 2009. "Indian Community College System: Democratic Response to Globalization." In Community College Models: Globalization and Higher Education Reform, ed. Rosalind Latiner Raby and Edward J. Valeau (pp. 79-90). Dordrecht, The Netherlands: Springer Publishers.

American Association of Community Colleges. 2014. Framework of Accountability. Available online at: http://vfa.aacc.nche.edu.

Anazi, Shinobu, and Chie Matsuzawa Paik. 2012. "Factors Influencing Japanese Women to Choose Two-Year Colleges in Japan." Community College Journal of Research and Practice 36 (8): 614-625.

Aypay, Ahmet. 2008. "The Vocational and Technical Schools of Higher Education in Turkey." In Global Development of Community Colleges, and Further Education Programs, ed. Paul A. Elsner, George R. Boggs, and Judith T. Irwin. Washington, DC: Community College Press.

Bègin-Caouette, Olivier. 2013. "Think Locally, Act Globally: Comparing Urban, Suburban, and Rural Colleges' Internationalization: The Case of the CÉGEPS." College Quarterly 16 (4): 9-19.

Bourdieu, Pierre, and Jean-Claude Passeron. 1977. Reproduction in Education, Society and Culture. London: SAGE.

Butler, Norman L., Catherine Smith, Barry Davidson, Tyrone Tanner, and William Allan Kritsonis. 2008. "Polish PostSecondary Vocational Schools vs. Canadian Community Colleges: A Comparison of Information Accessibility and Accountability Submission." Lamar University Electronic Journal of Student Research. Available online at: http://www.eric.ed.gov/PDFS/ED502177.pdf.

Carnevale, Anthony P., Stephen J. Rose, and Andrew R. Hanson. 2012. Certificates: Gateway to Gainful Employment and College Degrees. Washington, DC: University Center on Education and the Workforce Press, Georgetown University.

Chen, Dandan. 2009. Vocational Schooling, Labor Market Outcomes, and College Entry. Policy Research Working Paper No. WPS 4814. Washington, DC: World Bank. Available online at: http://documents.worldbank.org.

Chen, Amy Shi-min, and Wei-ni Wang. 2009. "From Education to Grassroots Learning: Towards a Civil Society Through Community Colleges in Taiwan." In Community College Models: Globalization and Higher Education Reform, ed. Rosalind Latiner Raby and Edward J. Valeau (pp. 51-70). Dordrecht, The Netherlands: Springer Publishers.

Commons, Patrick Kevin. 2003. "The Contributions of Inspection, Self-Assessment, Investors in People and the Inclusive Learning Quality Initiative to Improving Quality in Further Education Sector Colleges: An Initial Exploration." Journal of Further and Higher Education 27 (1): 27-46.
Colleges and Institutes Canada (CIC). 2014. About. Available online at: www.collegesinstitutes.ca/about/.

Davidovitch, Nitza, and Yaacov Iram. 2009. "College-University Divide: from Confrontation to Cooperation." In Community College Models: Globalization and Higher Education Reform, ed. Rosalind Latiner Raby and Edward J. Valeau (pp. 373400). Dordrecht, The Netherlands: Springer Publishers.

Dellow, Donald A. 2007. "The Role of Globalization in Technical and Occupation Programs." New Directions for Community Colleges 138: 39-45.

de Moura Castro, Claudio, and Norma M. Garcia, eds. 2003. Community Colleges: A Model for Latin America? Washington, DC: Inter-American Development Bank, Johns Hopkins University Press.

DoBell, Daniel C., and Sarah A. Ingle. 2009. "Pathways to Participation: A Comparative Study of Community College Entrepreneurial Educational Programs in the United States and Ireland." In Community College Models: Globalization and Higher Education Reform, ed. Rosalind Latiner Raby and Edward J. Valeau (pp. 481-500). Dordrecht, The Netherlands: Springer Publishers.

Elsner, Paul A., George R. Boggs, and Judith T. Irwin, eds. 2008. Global Development of Community Colleges, Technical Colleges, and Further Education Programs. Washington, DC: Community College Press, American Association of Community Colleges.

Epperson, Cynthia K. 2012. "The Evolving Community College Model in the Socialist Republic of Viet Nam." In Community Colleges Worldwide: Investigating the Global Phenomenon, ed. Alexander W. Wiseman, Audree Chase-Mayoral, Thomas Janis, and Anuradha Sachdev (pp. 299-327). Bingley, UK: Emerald Publishing.

Glander-Dolo, Mackenzie S. 2011. "Première Université Régionale du Mali-education Distance (Prem-U): Challenges and Insights for Ubiquitous Education." Ubiquitous Learning: An International Journal 3 (2): 9-19.

Gregorutti, Gustavo. 2012. "The Mexican Idea of Two-Year University Degrees: A Model of Opportunities and Challenges." In Community Colleges Worldwide: Investigating the Global Phenomenon, ed. Alexander W. Wiseman, Audree ChaseMayoral, Thomas Janis, and Anuradha Sachdev (pp. 49-71). Bingley, UK: Emerald Publishing.

Gueye, Barrel, and Ibra Sene. 2009. "A Critical Approach of the Community College Model in the Global Order: The College Universitaire Régional of Bambey (Senegal) as a Case Study." In Community College Models: Globalization and Higher Education Reform, ed. Rosalind Latiner Raby and Edward J. Valeau (pp. 235-252). Dordrecht, The Netherlands: Springer Publishers.

Hall, Geoff, and Hugh David. 2008. "From Demand-Led Skills to the Entrepreneurial College in England." In Global Development of Community Colleges, and Further Education Programs, ed. Paul A. Elsner, George R. Boggs, and Judith T. Irwin. Washington, DC: Community College Press. 
Hagedorn, Linda Serra, and Wafa Thabet Mezghani. 2013. "Bringing Community Colleges to Tunisia." New Directions for Community Colleges 161: 101-111.

Harbour, Clifford P., and Ozan Jaquette. 2007. "Advancing an Equity Agenda at the Community College in an Age of Privatization, Performance Accountability, and Marketization." Equity and Excellence in Education 40 (3): 197-207.

Herault, Nicolas, Rezida Zakirova, and Hielke Buddelmeyer. 2012. National Centre for Vocational Education Research (NCVER). Melbourne: Australian Department of Education Employment and Workplace Relations.

Hyland, Terry, and Barbara Merrill. 2003. The Changing Face of Further Education: Lifelong Learning, Inclusion and Community Values in Further Education. London: Routledge Falmer.

Jansen, Jonathan D. 2003. "The State of Higher Education in South Africa: From Massification to Mergers." In State of the Nation: South Africa 2003-2004, ed. John Daniel, Adam Habib, and Roger Southall (pp. 290-311). Pretoria: HSRC Press.

Jephcote, Martin. 2011. "The Unintended Consequences of Funding Policies on Student Achievement at Colleges of Further Education in Wales and England." In Increasing Effectiveness of the Community College Financial Model: A Global Perspective for the Global Economy, ed. Stewart E. Sutin, Daniel Derrico, Edward J. Valeau, and Rosalind L. Raby. New York: Palgrave Macmillan Publishers.

Jephcote, Martin, and Rosalind L. Raby. 2012. "A Comparative View of Colleges of Further Education (UK) and Community Colleges (US): Maintaining Access in an Era of Financial Constraint." Research in Post-Compulsory Education 17 (3): 349366.

Katsinas, Stephen G., and Terrence A. Tollefson. 2009. Funding and Access Issues in Public Higher Education: A Community College Perspective. Tuscaloosa, AL: Education Policy Center, University of Alabama.

Kintzer, Federick C. 1979. "World Adaptations to the Community College Concept." New Directions for Community Colleges 26: 65-78.

Kintzer, Federick. 1994. Higher Education Approaches the 21st Century: New Perspectives on Non-universities. Presentation to the Nova Southeastern University, August.

Levin, John S. 2001. Globalizing the Community College: Strategies for Change in the Twenty-First Century. New York: Palgrave.

Lewin, Keith M. 2007. "Diversity in Convergence: Access to Education for All." Compare: A Journal of Comparative Education 37 (5): 577-601.

Li, Sophia. 2010. "Chiles-First Community College." Chronicle of Higher Education, November 9. Available online at: http://chronicle.com/article/Chiles-FirstCommunity $/ 125272 /$ ?sid $=$ cc\&utm source $=$ cc\&utm medium $=$ en .

Longden, Bernard. 2013. "Bearing Down on Student NonCompletion: Implications and Consequences for English Higher Education. Journal of College Student Retention: Research, Theory \& Practice 14 (1): 117-147.
Lowe, Janet, and Gayle Vernon. 2007. "Exploring the Work/Life/Study Balance: The Experience of Higher Education Students in a Scottish Further Education College." Journal of Further and Higher Education 31 (3): 225-239.

Marmolejo, Francisco. 2010. "Two Year Colleges: Second-class Citizens in the World of Higher Education." Chronicle of Higher Education, August 18. Available online at: http://chronicle.com/blogs/worldwise/2-year-colleges-secondclass-citizens-in-the-world-of-higher-education/26305.

Meehan, Mark W. 2012. Islam, Modernity, and the Liminal Space Between: A Vertical Case Study of the Institute of Traditional Islamic Art and Architecture in Amman, Jordan. Unpublished Dissertation, Department of Educational Administration, Higher Education Leadership, College of Education, University of South Carolina.

Morris, Camille. 2012. Community College Model in Anglophone Caribbean: Relevance and Future. Paper Presented at the Comparative and International Education Society (CIES) National Conference, San Juan, Puerto Rico, 22-27 April 2012.

Mpondi, Douglas. 2009. "Community Colleges and the Globalization of Higher Education in Postcolonial Zimbabwe." In Community College Models: Globalization and Higher Education Reform, ed. Rosalind L. Raby and Edward J. Valeau. (pp. 7178). Dordrecht, The Netherlands: Springer Publishers.

Mullin, Christopher. 2011. The Road Ahead: A Look at Trends in the Educational Attainment of Community College Students. Washington, DC: American Association of Community Colleges. Available online at: http://www.aacc.nche.edu/Publications/Briefs/Pages/pb09292011.aspx.

Nixon, Gordon. 2011. "Revenue Generation Through Training a Global Energy Workforce." In Increasing Effectiveness of the Community College Financial Model: A Global Perspective for the Global Economy, ed. Stewart E. Sutin, Daniel Derrico, Edward J. Valeau, and Rosalind L. Raby. New York: Palgrave Macmillan Publishers.

Organisation for Economic Co-operation and Development (OECD). 2014. Education at a Glance 2014: OECD Indicators. Paris, France: OECD Publishing. Available online at: http://dx.doi.org/10.1787/eag-2014-en.

Panwar, B. S. 2013. "Applying the U.S. Community College Model to India: Indian Perspectives on The Indian Community College System: Developing Vocational Education in India." In The U.S. Community College Model: Potential for Applications in India. (pp. 14-17). Available online at: http://www.iie.org/en/Research-and-Publications/Publicationsand-Reports/IIE-Bookstore/US-Community-College-ModelPotential-For-Applications-In-India.

Psacharopoulos, George, and Maureen Woodhall. 1985. Education for Development: An Analysis of Investment Choices. Balitmore, MD: John Hopkins University Press.

Raby, Rosalind L., and Edward J. Valeau. 2009. Community College Models: Globalization and Higher Education Reform. Dordrecht, The Netherlands: Springer Publishers. 
Raby, Rosalind L. 2010. "Patterns of Internationalization in the Field: A Review of the 2009 CER Bibliography." Comparative Education Review 53 (3): 415-427.

Raby, Rosalind L., and Edward J. Valeau. 2013. "Community College Global Counterparts: Historical Contexts." Research in Comparative and International Education 8 (2): 110-118.

Riordan, Martian. ed. 2008. TAFE Directors Australia Occasional Paper Series. Melbourne: TAFE Publishers.

Roksa, Josipa, and Juan Carlos Calcagno. 2010. "Catching up in Community Colleges: Academic Preparation and Transfer to Four-Year Institutions." Teachers College Record 112 (1): 260-288.

Schofield, Cathy, and Harriet Dismore. 2010. "Predictors of Retention and Achievement of Higher Education Students Within a Further Education Context." Journal of Further and Higher Education 34 (2): 207-221.

Schultz, Theodore W. 1961. "Investment in Human Capital." American Economic Review 51 (1): 1-17.

Scott, David J. 2009. "A Closer Look at Completion in Higher Education in New Zealand." Journal of Higher Education Policy \& Management 31 (2): 101-108.

Scott, Peter. 2010. "International Education: Alternatives to the Market." International Higher Education 61 (1): 1-2.

Shumaker, John W. 2013. "U.S. Community Colleges and a Response to the Arab Spring." New Directions for Community Colleges 161: 113-127.

Spangler, Mary S., and Arthur Q. Tyler. 2011. "Identifying Fit of Mission and Environment: Applying the American Community College Model Internationally." New Directions for Higher Education 155: 41-52.

Spindler, George D., and Louise Spindler. 1992. "Cultural Process and Ethnography: An Anthropological Perspective." In The Handbook of Qualitative Research in Education, ed. Margaret D. LeCompte, Wendy L. Millroy, and Judith Preissle. San Diego, CA: Academic Press.

Strydom, A. H., and L. O. K. Lategan, eds. 1998. Introducing Community Colleges to South Africa. Bloemfontein, South Africa: University of the Free State Publications.

Teichler, Ulrich. 2004. "Changing Structures of Higher Education Systems: The Increasing Complexity of Underlying Forces." UNESCO Forum, Occasional Papers No. 6, The Diversification of Higher Education and the Changing Role of Knowledge Systems. Paris: UNESCO.

Treat, Tod, and Linda Serra Hagedorn. 2013. "Resituating the Community College in a Global Context." New Directions for Community Colleges 161: 5-9.

Trow, Martin. 1973. Problems in the Transition from Elite to Mass Higher Education. Carnegie Commission on Higher Education. Berkeley, California: McGraw-Hill. Available online at: http://www.eric.ed.gov/PDFS/ED091983.pdf.

Wiseman, Alexander W., Audree Chase-Mayoral, Thomas Janis, and Anuradha Sachdev. 2012. "Community Colleges: Where Are They (Not?).” In Community Colleges Worldwide: Investigating the Global Phenomenon, ed. Alexander W. Wiseman,
Audree Chase-Mayoral, Thomas Janis, and Anuradha Sachdev Bingley. UK: Emerald Publishing.

World Bank. 2008. Vietnam - Higher Education and Skills for Growth. Washington, DC: The World Bank. Available online at: http://documents.worldbank.org/curated/en/2008/06/10988339/ vietnam-higher-education-skills-growth. 